\title{
MARKET PARTICIPATION VARIABLES IN COMMERCIALIZING SOUTH AFRICAN SMALLHOLDER FARMERS.
}

\author{
Nwafor, Christopher Ugochukwu \\ manchrizzo@ hotmail.com
}

Department of Agriculture, Central University of Technology, South Africa

\begin{abstract}
The study examined key socio-economic characteristics of smallholder farmers identified for their contribution to market participation. These variables include gender, age, marital status, level of education, household size, additional income, membership of cooperative, herd size and use of ICTs. Using a structured questionnaire, primary data was collected from a total of 129 respondents which was analysed with the Statistical Package for the Social Sciences, and presented using cross-tabulations, percentages and count data. The result indicates that age, additional income, cooperative membership and use of ICTs were important variables which contributed to market participation among respondents. The study also made applicable recommendations as the findings may have relevance for future research, policy and practice for commercializing smallholder farmers.
\end{abstract}

Keywords: additional income, commercialization, cooperative membership, market participation, smallholder farmer, variables.

\section{Introduction:}

Commercialization has been promoted as a viable approach to address the controversy pertaining to the lack of progress in integrating smallholder farmers into the South African mainstream economy. Nwafor \& Westhuizen (2020) as well as Neves \& Du Toit (2013) including many others studies have outlined the glaring contrast between the commercial and smallholder sectors of the agricultural economy, amid various government policies and targeted programmes designed to support the development of smallholder farmers. Within this context, commercialization is considered a primary strategy for transforming the smallholder agricultural sector. There is a commonly held viewpoint that a reduction in the market access barriers will facilitate the transition of smallholder farmers into the mainstream economy (Baloyi \& Anim 2018; Khapayi \& Celliers 2016), which will translate into reduction in poverty levels among a majority of the smallholders, an improvement in their household food security situation, as well as fast-tracking agricultural development leading to improved economy-wide growth (Ngqangweni, Mmbengwa et al. 2016). 
The needs of smallholder farmers and their developmental perspectives have continued to gain prominence, rising to the forefront of the political, economic and research agenda in many developing countries (United Nations, 2012), and centred primarily on smallholdersector commercialisation and modernisation for stimulating economic growth and enhancing food security (Martey et al., 2014). However, the difficulties encountered by smallholders in market participation have been well documented (Badiane 2014), and costs related to obtaining market information, including a lack of reliable information on markets are identified as impeding factors to smallholder commercialisation (Matous et al., 2015; Milovanovic, 2014).

The concept of commercialization among smallholder farmers has been variously defined in the market access literature, and includes the proportion of output sold in the market (Pradhan et al. 2010) or their integration into value-chains (Barrett et al. 2010). Recent views of commercialization have emphasized the degree of engagement with markets, either for input or output (Okezie et al. 2012). Commercialization as applied to the South African smallholder farmer implies a transformation from subsistence production to engagement with formal markets through reacting to current production and marketing signals, and hence becoming a participant in the mainstream economy. It is an on-going process that requires market access, and depends on the market orientation and market participation of the smallholder farmers.

A key avenue for achieving commercialization among smallholder farmers is through the elimination of challenges they face in accessing markets, or by reducing the impact of factors that hinder their market access. A major factor identified (Okello et al. 2014) is information cost, which comprise primarily of the associated costs in searching, screening, obtaining, and verifying market information, including bargaining costs. However, in most developing economies such as South Africa, smallholder farmers find it difficult to participate in markets because of numerous constraints and barriers. Many of these barriers relate to their need for market information (Jari \& Fraser 2012), which require systems or sources that are considered responsive to the context of smallholder farmers. These information costs can be ameliorated using effective market information systems anchored on existing ICT infrastructure and tools.

Nwafor et al. (2020) contended that while ICTs may not be considered as a solution to all the market challenges of smallholder farmers, they can make a meaningful contribution, 
especially for information-impacting decisions. ICTs such as radio, television, mobile phones, multi-media platforms and internet enabled computers are considered paramount for providing smallholder farmers with market information, while simultaneously reducing existing market asymmetries. ICT-enabled sources facilitate improved market transparency, enhanced incomes and other positive welfare outcomes. Nonetheless, the utilization of ICTbased market information sources and market participation among smallholder farmers is influenced by their socio-economic features (Nwafor 2019). This position is supported in the literature (Okello et al. 2014; Mwombe et al. 2013; Chirwa and Matita 2012), where important determinants of market participation and utilization of ICTs were influenced by the personal and farm-specific characteristics of smallholder farmers.

These socio-economic features relevant for market participation among smallholder farmers include their gender, age, marital status, household size, education, additional income source, membership of farmer association, herd size (livestock) or quantity of produce (crop) and the use of ICTs for market information. The present study hence examined socio-economic variables contributing to increased market participation among smallholder livestock farmers within the study area, and the study contributes to addressing one of the components of commercialization aimed at enhancing their engagement with the mainstream economy. It is guided by the research question; what are the important variables in market access among smallholder farmers, and how do these variables contribute to the market participation of smallholder farmers.

\section{Methodology}

\section{Study area:}

The study was conducted within the Alfred Nzo District Municipality (ANDM) of Eastern Cape Province in South Africa. The study area was chosen due to its rural nature with a preponderance of smallholder farmers. It experiences adequate rainfall amounts of between 700-1000 mm mainly in the summer season, with substantial difference between areas around the coast than inland areas. Warm summers and cold winter periods dominate, though inland areas experience some frost during winter while the coastal fringe is mostly frost-free. Subsistence agriculture is mostly practiced, within the extensive communal grassland and the district comprises four local municipalities namely Matatiele, Umzimvubu, Ntabankulu and Mbizana shown in the Figure 1. 


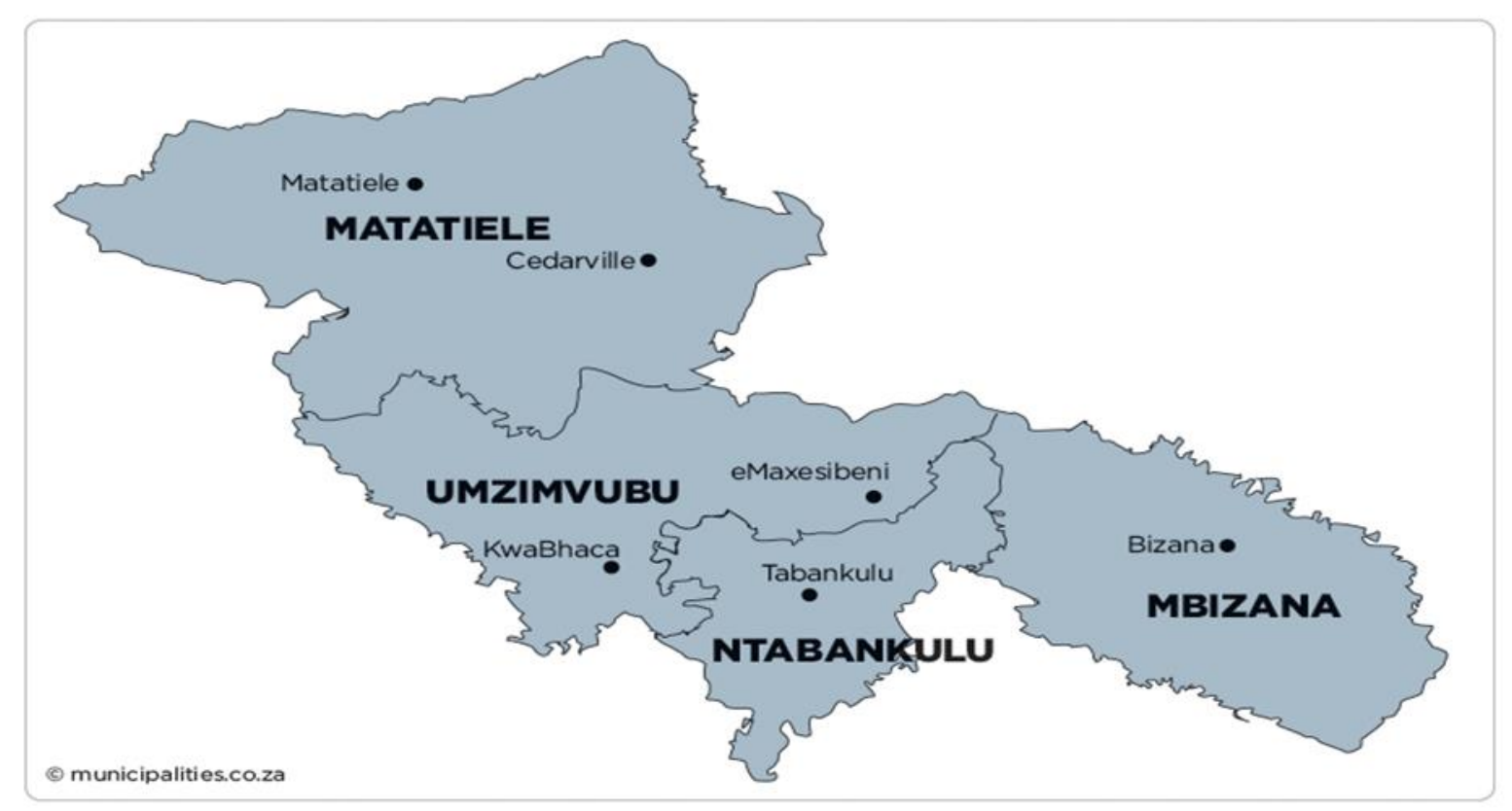

Figure 1: Map of Alfred Nzo District showing the local municipalities

Source: https://municipalities.co.za/map/101/alfred-nzo-district-municipality

\section{Data collection \& Sampling}

A structured schedule was prepared and used to collect primary data from respondents in this study. Sections in the schedule consisted of individual demographic characteristics, asset ownership, ICT tools used, information on market participation and output sold. A total of 150 livestock farmers were interviewed during the survey between June and October 2018. A multi-stage procedure was utilized to identify respondents from the study population and for the collection of data. Three local municipalities in the Alfred Nzo District were purposively selected in the first stage; while in the second stage, one Ward within each local municipality was randomly selected from a list of Wards. In the final stage, 10 livestock farmers were sampled using a snowball method.

\section{Analysis and presentation:}

The data collected was verified and entered onto an SPSS database for analysis, and during the data-cleaning and entry exercise some schedules were discarded due to incomplete entry, leaving a total of 129 valid entries. The data is presented using descriptive analysis in tables below, to show percentages and counts from the cross-tabulation of each examined variables. 


\section{Results}

\section{Gender and market participation}

The gender of respondents was cross-tabulated with market participation from the data obtained and result is shown in Table 1.

Table 1. Gender and market participation count

\begin{tabular}{|c|c|c|c|c|c|}
\hline & & & \multicolumn{2}{|c|}{ Participate in markets } & \multirow{2}{*}{ Total } \\
\hline & & & No & Yes & \\
\hline \multirow{8}{*}{ Gender } & \multirow{4}{*}{ Female } & Count & 8 & 39 & 47 \\
\hline & & \% within Gender of respondent & $17.0 \%$ & $83.0 \%$ & $100.0 \%$ \\
\hline & & $\%$ within Participate in markets & $26.7 \%$ & $39.4 \%$ & $36.4 \%$ \\
\hline & & $\%$ of Total & $6.2 \%$ & $30.2 \%$ & $36.4 \%$ \\
\hline & \multirow{4}{*}{ Male } & Count & 22 & 60 & 82 \\
\hline & & $\%$ within Gender of respondent & $26.8 \%$ & $73.2 \%$ & $100.0 \%$ \\
\hline & & $\%$ within Participate in markets & $73.3 \%$ & $60.6 \%$ & $63.6 \%$ \\
\hline & & $\%$ of Total & $17.1 \%$ & $46.5 \%$ & $63.6 \%$ \\
\hline \multirow{4}{*}{ Total } & & Count & 30 & 99 & 129 \\
\hline & & $\%$ within Gender of respondent & $23.3 \%$ & $76.7 \%$ & $100.0 \%$ \\
\hline & & \% within Participate in markets & $100.0 \%$ & $100.0 \%$ & $100.0 \%$ \\
\hline & & $\%$ of Total & $23.3 \%$ & $76.7 \%$ & $100.0 \%$ \\
\hline
\end{tabular}

The data suggests that approximately $83 \%$ of female respondents participated in markets while $17 \%$ did not participate. While $73 \%$ of males participated in market, $27 \%$ did not participate. In comparison, females constitute $36 \%$ of total number of respondents participating in markets and males made up 64\%. This figure reflects the gender composition of respondents in the study. The survey data indicate that as many women participated in markets, as their male counterparts, based on gender composition

\section{Age and market participation:}

The respondents were classified into age groups and the groups cross-tabulated with market participation, as shown in Table 2. 
Table 2: Age and market participation count among survey respondents

\begin{tabular}{|c|c|c|c|c|c|}
\hline & & & \multicolumn{2}{|c|}{ Participate in markets } & \multirow{2}{*}{ Total } \\
\hline & & & No & Yes & \\
\hline \multirow{16}{*}{ Age of respondent } & \multirow{4}{*}{$18-35 y r s$} & Count & 5 & 4 & 9 \\
\hline & & $\%$ within Age of respondent & $55.6 \%$ & $44.4 \%$ & $100.0 \%$ \\
\hline & & $\%$ within Participate in markets & $16.7 \%$ & $4.0 \%$ & $7.0 \%$ \\
\hline & & $\%$ of Total & $3.9 \%$ & $3.1 \%$ & $7.0 \%$ \\
\hline & \multirow{4}{*}{$36-45 y r s$} & Count & 0 & 22 & 22 \\
\hline & & $\%$ within Age of respondent & $0.0 \%$ & $100.0 \%$ & $100.0 \%$ \\
\hline & & $\%$ within Participate in markets & $0.0 \%$ & $22.2 \%$ & $17.1 \%$ \\
\hline & & $\%$ of Total & $0.0 \%$ & $17.1 \%$ & $17.1 \%$ \\
\hline & \multirow{4}{*}{ 46-55yrs } & Count & 4 & 17 & 21 \\
\hline & & $\%$ within Age of respondent & $19.0 \%$ & $81.0 \%$ & $100.0 \%$ \\
\hline & & $\%$ within Participate in markets & $13.3 \%$ & $17.2 \%$ & $16.3 \%$ \\
\hline & & $\%$ of Total & $3.1 \%$ & $13.2 \%$ & $16.3 \%$ \\
\hline & \multirow{4}{*}{ 56yrs and above } & Count & 21 & 56 & 77 \\
\hline & & $\%$ within Age of respondent & $27.3 \%$ & $72.7 \%$ & $100.0 \%$ \\
\hline & & $\%$ within Participate in markets & $70.0 \%$ & $56.6 \%$ & $59.7 \%$ \\
\hline & & $\%$ of Total & $16.3 \%$ & $43.4 \%$ & $59.7 \%$ \\
\hline \multirow{4}{*}{ Total } & & Count & 30 & 99 & 129 \\
\hline & & $\%$ within Age of respondent & $23.3 \%$ & $76.7 \%$ & $100.0 \%$ \\
\hline & & $\%$ within Participate in markets & $100.0 \%$ & $100.0 \%$ & $100.0 \%$ \\
\hline & & $\%$ of Total & $23.3 \%$ & $76.7 \%$ & $100.0 \%$ \\
\hline
\end{tabular}

The collected data shows that $44 \%$ of those between $18-35$ years participated in markets, all respondents aged 36-45 years participated, while 81\% of respondents $46-55$ years also participated in markets. Additionally, among the respondents who are 56 years and above, approximately $73 \%$ participated in markets. The numbers of those between $36-45$ years show active market participation as the data indicate $100 \%$ market participation. The percentage participation among respondents 46 -55 years and 56+ showed a slight decline at $81 \%$ and $73 \%$ respectively, though their market participation was higher than those in the 18-35year bracket.

\section{Marital status and market participation:}

The marital status of respondents was used to explore for any differences in market participation, and result is shown in Table 3 comprising four categories of respondents. 
Table 3. Marital status and market participation count

\begin{tabular}{|c|c|c|c|c|c|}
\hline & & & Partici & larkets & \\
\hline & & & No & Yes & Total \\
\hline & & Count & 9 & 26 & 35 \\
\hline & Sinqle & $\%$ within Marital status & $25.7 \%$ & $74.3 \%$ & $100.0 \%$ \\
\hline & & $\%$ within Participate in markets & $30.0 \%$ & $26.3 \%$ & $27.1 \%$ \\
\hline & & $\%$ of Total & $7.0 \%$ & $20.2 \%$ & $27.1 \%$ \\
\hline & & Count & 12 & 47 & 59 \\
\hline Marital status & & $\%$ within Marital status & $20.3 \%$ & $79.7 \%$ & $100.0 \%$ \\
\hline & Married & $\%$ within Participate in markets & $40.0 \%$ & $47.5 \%$ & $45.7 \%$ \\
\hline & & $\%$ of Total & $9.3 \%$ & $36.4 \%$ & $45.7 \%$ \\
\hline & Divorced & Count & 0 & 4 & 4 \\
\hline & & $\%$ within Marital status & $0.0 \%$ & $100.0 \%$ & $100.0 \%$ \\
\hline & & $\%$ within Participate in markets & $0.0 \%$ & $4.0 \%$ & $3.1 \%$ \\
\hline & & $\%$ of Total & $0.0 \%$ & $3.1 \%$ & $3.1 \%$ \\
\hline & widowed & Count & 9 & 22 & 31 \\
\hline & & $\%$ within Marital status & $29.0 \%$ & $71.0 \%$ & $100.0 \%$ \\
\hline & & \% within Participate in markets & $30.0 \%$ & $22.2 \%$ & $24.0 \%$ \\
\hline & & $\%$ of Total & $7.0 \%$ & $17.1 \%$ & $24.0 \%$ \\
\hline & & Count & 30 & 99 & 129 \\
\hline Total & & \% within Marital status & $23.3 \%$ & $76.7 \%$ & $100.0 \%$ \\
\hline & & $\%$ within Participate in markets & $100.0 \%$ & $100.0 \%$ & $100.0 \%$ \\
\hline & & $\%$ of Total & $23.3 \%$ & $76.7 \%$ & $100.0 \%$ \\
\hline
\end{tabular}

Among the respondents, $27 \%$ were single and $46 \%$ married, those divorced were $3 \%$ and widowed respondents comprise $24 \%$. While $74 \%$ of single respondents participated in the market, $26 \%$ did not participate. Also, $80 \%$ of married respondents participated in market and $20 \%$ did not participate. All respondents classified under 'divorced' had participated, and among the widowed respondents, $71 \%$ participated while $29 \%$ did not participate. The market participation percentages among the groups were within the same range $(74 \%, 80 \%$ and $71 \%)$ suggesting that marital status of respondents made no contribution to their market participation.

\section{Education and market participation}

Respondents were classified according to the level of education (proxy by number of years spent in school), and the groups cross-tabulated based on their participation in market. The result is presented in Table 4 with five categories of respondents. 
Table 4. Education and market participation count

\begin{tabular}{|c|c|c|c|c|c|}
\hline & & & \multicolumn{2}{|c|}{ Participate in markets } & \multirow{2}{*}{ Total } \\
\hline & & & No & Yes & \\
\hline \multirow{20}{*}{ Level of education } & \multirow{4}{*}{ None } & Count & 4 & 18 & 22 \\
\hline & & $\%$ within Level of education & $18.2 \%$ & $81.8 \%$ & $100.0 \%$ \\
\hline & & $\%$ within Participate in markets & $13.3 \%$ & $18.2 \%$ & $17.1 \%$ \\
\hline & & $\%$ of Total & $3.1 \%$ & $14.0 \%$ & $17.1 \%$ \\
\hline & \multirow{4}{*}{ Primary } & Count & 13 & 34 & 47 \\
\hline & & $\%$ within Level of education & $27.7 \%$ & $72.3 \%$ & $100.0 \%$ \\
\hline & & $\%$ within Participate in markets & $43.3 \%$ & $34.3 \%$ & $36.4 \%$ \\
\hline & & $\%$ of Total & $10.1 \%$ & $26.4 \%$ & $36.4 \%$ \\
\hline & \multirow{4}{*}{ Junior High school } & Count & 0 & 7 & 7 \\
\hline & & $\%$ within Level of education & $0.0 \%$ & $100.0 \%$ & $100.0 \%$ \\
\hline & & $\%$ within Participate in markets & $0.0 \%$ & $7.1 \%$ & $5.4 \%$ \\
\hline & & $\%$ of Total & $0.0 \%$ & $5.4 \%$ & $5.4 \%$ \\
\hline & \multirow{4}{*}{ High school } & Count & 4 & 14 & 18 \\
\hline & & $\%$ within Level of education & $22.2 \%$ & $77.8 \%$ & $100.0 \%$ \\
\hline & & $\%$ within Participate in markets & $13.3 \%$ & $14.1 \%$ & $14.0 \%$ \\
\hline & & $\%$ of Total & $3.1 \%$ & $10.9 \%$ & $14.0 \%$ \\
\hline & \multirow{4}{*}{ Tertiary } & Count & 9 & 26 & 35 \\
\hline & & $\%$ within Level of education & $25.7 \%$ & $74.3 \%$ & $100.0 \%$ \\
\hline & & $\%$ within Participate in markets & $30.0 \%$ & $26.3 \%$ & $27.1 \%$ \\
\hline & & $\%$ of Total & $7.0 \%$ & $20.2 \%$ & $27.1 \%$ \\
\hline \multirow{4}{*}{ Total } & & Count & 30 & 99 & 129 \\
\hline & & $\%$ within Level of education & $23.3 \%$ & $76.7 \%$ & $100.0 \%$ \\
\hline & & $\%$ within Participate in markets & $100.0 \%$ & $100.0 \%$ & $100.0 \%$ \\
\hline & & $\%$ of Total & $23.3 \%$ & $76.7 \%$ & $100.0 \%$ \\
\hline
\end{tabular}

Approximately, $82 \%$ of respondents with no education participated in markets, $72 \%$ of respondents with a primary education participated in markets, all respondents with a junior high school education (comprising only $5 \%$ of respondents) participated, with $78 \%$ and $74 \%$ of respondents with High School and Tertiary education respectively, also participating in markets. Though all respondents with a junior high school level education participated in markets, there was an almost equal percentage of market participation among the groups based on different levels of education.

\section{Household size and market participation}

Respondents were classified according to number of persons in their household, in 3 groups and the number of respondents participating in markets between the groups cross-tabulated, as result is shown in Table 5. 
Table 5. Household size and market participation count

\begin{tabular}{|c|c|c|c|c|c|}
\hline & & & \multicolumn{2}{|c|}{ Participate in markets } & \multirow{2}{*}{ Total } \\
\hline & & & No & Yes & \\
\hline \multirow{12}{*}{ Household size } & \multirow{4}{*}{ 2-4persons } & Count & 9 & 29 & 38 \\
\hline & & \% within Household size & $23.7 \%$ & $76.3 \%$ & $100.0 \%$ \\
\hline & & \% within Participate in markets & $30.0 \%$ & $29.3 \%$ & $29.5 \%$ \\
\hline & & $\%$ of Total & $7.0 \%$ & $22.5 \%$ & $29.5 \%$ \\
\hline & \multirow{4}{*}{ 5-7persons } & Count & 14 & 54 & 68 \\
\hline & & \% within Household size & $20.6 \%$ & $79.4 \%$ & $100.0 \%$ \\
\hline & & $\%$ within Participate in markets & $46.7 \%$ & $54.5 \%$ & $52.7 \%$ \\
\hline & & $\%$ of Total & $10.9 \%$ & $41.9 \%$ & $52.7 \%$ \\
\hline & \multirow{4}{*}{ 8-10persons } & Count & 7 & 16 & 23 \\
\hline & & $\%$ within Household size & $30.4 \%$ & $69.6 \%$ & $100.0 \%$ \\
\hline & & $\%$ within Participate in markets & $23.3 \%$ & $16.2 \%$ & $17.8 \%$ \\
\hline & & $\%$ of Total & $5.4 \%$ & $12.4 \%$ & $17.8 \%$ \\
\hline \multirow{4}{*}{ Total } & & Count & 30 & 99 & 129 \\
\hline & & $\%$ within Household size & $23.3 \%$ & $76.7 \%$ & $100.0 \%$ \\
\hline & & \% within Participate in markets & $100.0 \%$ & $100.0 \%$ & $100.0 \%$ \\
\hline & & $\%$ of Total & $\mathbf{2 3 . 3} \%$ & $76.7 \%$ & $100.0 \%$ \\
\hline
\end{tabular}

The data in Table 5 shows that $76 \%$ of respondents in small (2-4 persons) households, $79 \%$ of respondents in medium (5-7 persons) households and 70\% of respondents in large (8 persons and above) households participated in markets. Notwithstanding the number of persons in households, the different household groups participated almost equally in markets. This suggests that the size of household made no contribution towards participation in markets among respondents.

\section{Additional income and market participation}

The respondents were classified into two groups comprising those with, and without, an additional income source. The groups were then cross-tabulated with market participation and the result shown in Table 6. 
Table 6. Additional income source and market participation count

\begin{tabular}{|c|c|c|c|c|c|}
\hline & & & \multicolumn{2}{|c|}{ Participate in markets } & \multirow{2}{*}{ Total } \\
\hline & & & No & Yes & \\
\hline \multirow{8}{*}{ Other income source } & \multirow{4}{*}{ None } & Count & 4 & 42 & 46 \\
\hline & & $\%$ within Other income source & $8.7 \%$ & $91.3 \%$ & $100.0 \%$ \\
\hline & & $\%$ within Participate in markets & $13.3 \%$ & $42.4 \%$ & $35.7 \%$ \\
\hline & & $\%$ of Total & $3.1 \%$ & $32.6 \%$ & $35.7 \%$ \\
\hline & \multirow{4}{*}{ Yes } & Count & 26 & 57 & 83 \\
\hline & & $\%$ within Other income source & $31.3 \%$ & $68.7 \%$ & $100.0 \%$ \\
\hline & & \% within Participate in markets & $86.7 \%$ & $57.6 \%$ & $64.3 \%$ \\
\hline & & $\%$ of Total & $20.2 \%$ & $44.2 \%$ & $64.3 \%$ \\
\hline \multirow{4}{*}{ Total } & & Count & 30 & 99 & 129 \\
\hline & & $\%$ within Other income source & $23.3 \%$ & $76.7 \%$ & $100.0 \%$ \\
\hline & & \% within Participate in markets & $100.0 \%$ & $100.0 \%$ & $100.0 \%$ \\
\hline & & $\%$ of Total & $23.3 \%$ & $76.7 \%$ & $100.0 \%$ \\
\hline
\end{tabular}

The data in Table 6 shows that 36\% of respondents had no additional income source, while $64 \%$ of respondents had an additional income source. Among those without additional income source, only $42 \%$ participated in markets. On the other hand, for respondents with an additional income source, approximately $58 \%$ participated in markets.

Membership of farmer association and market participation count

Respondents were classified into two groups indicating their membership, or not, of a farmers' cooperative. The groups were then cross-tabulated with participation in market as shown in

Table 7. 
Table 7. Cooperative membership and market participation count

\begin{tabular}{|c|c|c|c|c|c|}
\hline & & & \multicolumn{2}{|c|}{ Participate in markets } & \multirow{2}{*}{ Total } \\
\hline & & & No & Yes & \\
\hline \multirow{8}{*}{ Member of cooperative } & \multirow{4}{*}{ No } & Count & 30 & 82 & 112 \\
\hline & & $\%$ within Member of cooperative & $26.8 \%$ & $73.2 \%$ & $100.0 \%$ \\
\hline & & $\%$ within Participate in markets & $100.0 \%$ & $82.8 \%$ & $86.8 \%$ \\
\hline & & $\%$ of Total & $23.3 \%$ & $63.6 \%$ & $86.8 \%$ \\
\hline & \multirow{4}{*}{ Yes } & Count & 0 & 17 & 17 \\
\hline & & $\%$ within Member of cooperative & $0.0 \%$ & $100.0 \%$ & $100.0 \%$ \\
\hline & & $\%$ within Participate in markets & $0.0 \%$ & $17.2 \%$ & $13.2 \%$ \\
\hline & & $\%$ of Total & $0.0 \%$ & $13.2 \%$ & $13.2 \%$ \\
\hline \multirow{4}{*}{ Total } & & Count & 30 & 99 & 129 \\
\hline & & $\%$ within Member of cooperative & $23.3 \%$ & $76.7 \%$ & $100.0 \%$ \\
\hline & & $\%$ within Participate in markets & $100.0 \%$ & $100.0 \%$ & $100.0 \%$ \\
\hline & & $\%$ of Total & $23.3 \%$ & $76.7 \%$ & $100.0 \%$ \\
\hline
\end{tabular}

Among respondents who were not members of a cooperative, $73 \%$ participated in markets while $27 \%$ did not participate. On the other hand, all respondents $(100 \%)$ who are members of a cooperative participated in the market. From another perspective, the Table 6 indicates that all respondents who did not participate in markets were not members of a farmer cooperative.

\section{Herd size and market participation}

The number of animals owned by respondents was also used for comparison among groups in relation to their market participation. Depending on the livestock numbers, respondents were classified into three groups with 50 or less animals, $51-100$ animals, and more than 100 animals respectively, as shown in Table 8 . 
Table 8. Herd size and market participation count

\begin{tabular}{|c|c|c|c|c|c|}
\hline & & & \multicolumn{2}{|c|}{ Participate in markets } & \multirow{2}{*}{ Total } \\
\hline & & & No & Yes & \\
\hline \multirow{12}{*}{ Number of animals } & \multirow{4}{*}{50 or less } & Count & 23 & 84 & 107 \\
\hline & & $\%$ within Number of animals & $21.5 \%$ & $78.5 \%$ & $100.0 \%$ \\
\hline & & $\begin{array}{lll}\begin{array}{c}\% \text { within } \\
\text { markets }\end{array} & \text { Participate in } \\
\end{array}$ & $76.7 \%$ & $\mathbf{8 4 . 8 \%}$ & $82.9 \%$ \\
\hline & & $\%$ of Total & $17.8 \%$ & $65.1 \%$ & $82.9 \%$ \\
\hline & \multirow{4}{*}{$51-100$} & Count & 4 & 9 & 13 \\
\hline & & \% within Number of animals & $30.8 \%$ & $69.2 \%$ & $100.0 \%$ \\
\hline & & $\begin{array}{l}\% \quad \text { within } \\
\text { markets }\end{array}$ & $13.3 \%$ & $9.1 \%$ & $10.1 \%$ \\
\hline & & $\%$ of Total & $3.1 \%$ & $7.0 \%$ & $10.1 \%$ \\
\hline & \multirow{4}{*}{ More than 100} & Count & 3 & 6 & 9 \\
\hline & & $\%$ within Number of animals & $33.3 \%$ & $66.7 \%$ & $100.0 \%$ \\
\hline & & $\begin{array}{lll}\begin{array}{c}\% \text { within } \\
\text { markets }\end{array} & \text { Participate in } \\
\end{array}$ & $10.0 \%$ & $6.1 \%$ & $7.0 \%$ \\
\hline & & $\%$ of Total & $2.3 \%$ & $4.7 \%$ & $7.0 \%$ \\
\hline \multirow{4}{*}{ Total } & & Count & 30 & 99 & 129 \\
\hline & & \% within Number of animals & $23.3 \%$ & $76.7 \%$ & $100.0 \%$ \\
\hline & & $\begin{array}{lll}\begin{array}{l}\text { within } \\
\text { markets }\end{array} & \text { Participate in } \\
\end{array}$ & $100.0 \%$ & $100.0 \%$ & $100.0 \%$ \\
\hline & & $\%$ of Total & $23.3 \%$ & $76.7 \%$ & $100.0 \%$ \\
\hline
\end{tabular}

Table 8 indicates that $83 \%$ of respondents had a herd size of '50 or less', respondents with herd sizes of '51-100' animals comprised 10\%, while those with 'more than 100' animals were about $7 \%$ of respondents. In the ' 50 or less' category, $78 \%$ of respondents participated in markets, while $22 \%$ of respondents did not participate in markets. Among the ' $51-100$ ' herd size category, $69 \%$ of respondents participated in markets and $31 \%$ did not participate. Furthermore, for those with 'more than 100' animals, $67 \%$ of respondents participated in the markets while $33 \%$ of respondents did not participate in the market. The figures obtained suggest a close level of market participation irrespective of herd size at $78 \%, 69 \%$ and $67 \%$ for the three groups respectively. While respondents with 'less than 50' animals had more market participation percentage, this could be attributed to the many more respondents in this category.

\section{Use of ICTs and market participation}

From the survey, respondents were classified into two categories of those using or not using ICT-based sources, and the result obtained among the categories is outlined in Table 9. 
Table 9. Use ICTs and market participation count

\begin{tabular}{|c|c|c|c|c|c|}
\hline & & & \multicolumn{2}{|c|}{ Participate in markets } & \multirow[t]{2}{*}{ Total } \\
\hline & & & No & Yes & \\
\hline \multirow{8}{*}{ Use ICT source } & \multirow{4}{*}{ No } & Count & 30 & 2 & 32 \\
\hline & & \% within Use ICT source & $93.8 \%$ & $6.3 \%$ & $100.0 \%$ \\
\hline & & \% within Participate in markets & $100.0 \%$ & $2.0 \%$ & $24.8 \%$ \\
\hline & & \% of Total & $23.3 \%$ & $1.6 \%$ & $24.8 \%$ \\
\hline & \multirow{4}{*}{ Yes } & Count & $\mathbf{0}$ & 97 & 97 \\
\hline & & \% within Use ICT source & $0.0 \%$ & $100.0 \%$ & $100.0 \%$ \\
\hline & & \% within Participate in markets & $0.0 \%$ & $\mathbf{9 8 . 0} \%$ & $75.2 \%$ \\
\hline & & \% of Total & $0.0 \%$ & $75.2 \%$ & $75.2 \%$ \\
\hline \multirow{4}{*}{ Total } & & Count & 30 & 99 & 129 \\
\hline & & \begin{tabular}{|l}
$\%$ within Use ICT source \\
\end{tabular} & $23.3 \%$ & $76.7 \%$ & $100.0 \%$ \\
\hline & & \% within Participate in markets & $100.0 \%$ & $100.0 \%$ & $100.0 \%$ \\
\hline & & \begin{tabular}{|l|}
$\%$ of Total \\
\end{tabular} & $23.3 \%$ & $76.7 \%$ & $100.0 \%$ \\
\hline
\end{tabular}

The data in Table 9 shows that $77 \%$ of respondents used ICT-based information sources and participated in markets, while $23 \%$ of respondents did not use ICT sources and also did not participate in the market. All users of ICT-based market information source participated in markets, making up a total of $98 \%$ of respondents who participated in markets. On the other hand, only $2 \%$ of those not using ICT-based market information sources participated in the markets. All respondents who did not use ICT-based information sources were non-market participants.

\section{Discussion}

The results from previous studies regarding the influence of gender on market participation provide divergent views. While some suggest a positive influence of gender on market participation (Reyes et al., 2012), others have reported that gender had no significant influence (Siziba et al. 2011). Notwithstanding conflicting comments regarding influence of gender on market participation, the literature recognises gender-based market imperfections which Mwangi et al. (2015) pointed to include significantly gendered differences in how resources, rights and responsibilities are allocated in many communities. Furthermore, the 
Food and Agriculture Organization (2010) recognized the gender inequalities related to land rights, and difficulties in accessing markets as a result of gender-bias in many social and cultural prescripts prevalent in the mainly rural communities where smallholders abound.

Smallholder farmers in the study aged between 36 - 45 years participated more in markets, than the 18-35year olds and those in older age brackets. This does not corroborate the position that age is an enabler of market participation held by some scholars such as Sebatta et al. (2014) and Asfaw et al. (2011). Considering the decline in participation percentage among older age groups in this survey, the study agrees with the postulation that market participation declines with age, posited by Musah et al. (2014), as well as Bahta and Bauer (2012) who pointed to risk aversion and conservative attitudes among older farmers. They noted that younger farmers had more enthusiasm to participate in markets, while concluding that age negatively influenced market participation. It is worth noting that many in the 18-35 years bracket could still be schooling, seeking formal work opportunities or do not own a farm.

The finding from this study is aligned with Nwalem et al. (2016) whereby the coefficient for marital status had no significant influence on market participation. However, marital status as an influencing factor in market participation among farmers elicits divergent views among scholars. Egbetokun and Omonona (2012) identified marital status as a major determining factor influencing participation in markets and reported a positive and significant impact. Contrarily, Adeoye and Adegbite (2018) stated a significant but negative effect of marital status on participation in markets.

Level of education made no difference to market participation of respondents in the study. This position is supported by conclusions from Mbitsemunda and Karangwa (2017) where they reported that level of education had no significant influence on market participation decisions of surveyed farmers. Sebatta et al. (2014) found a positive and significant influence of education on market participation, while Adeoti et al. (2014) reported that farmers' educational status showed a positive relationship with market participation from their study. On the contrary, Osmani and Hossain (2015) reported a significant but negative effect of education on market participation from their study; this was attributed to a motivation among educated household heads to seek other non-farm occupations.

This study reports that households participated equally in markets irrespective of size, and agrees with Arega et al. (2007) which reported that household size was insignificant in 
influencing market participation. In some studies, household size negatively influenced participation in markets (Martey et al. 2012; Siziba et al. 2011), whereby the size of household had an inverse relationship with market participation. This indicates that the propensity to participate in markets declined with increase in household size. On the contrary, Boughton et al. (2007) reported a positive influence of household size on market participation.

Comparatively, respondents with an additional income source participated more in markets than those without an additional income source. The result supports the position which highlights the usefulness of an additional income source for overcoming market entry costs among smallholder farmers (Barrett 2008). However, some studies have reported a significant but negative influence of additional income on market participation (Mbitsemunda and Karangwa 2017; Osmani and Hossein 2015), where increased off-farm income reduced market participation among smallholder farmers.

Membership of a farmer association or cooperative in this study contributed to market participation. This agrees with findings by Adenegan et al. (2012) and Batha and Bauer (2012), who reported improved quantities of output sold in the market among cooperative members. In their view, membership of a cooperative improved the production and marketing capabilities of farmers by strengthening their bargaining and lobbying power. It also served as a conduit of information to farmers which ultimately increased their participation in markets. Mathenge et al. (2010) hence reported a significant positive effect of cooperative membership on market participation. Some studies however, have reported a significant but negative relationship between membership of a cooperative and participation in markets (Abayne and Tefera 2013; Montshwe 2006), where farmers did not have an affiliation to any commodity group.

Size of herd among respondents in this study did not contribute to market participation, and the result is at variance with Bellemare and Barrett (2006) which found significant association between herd size and market participation. The result of their study suggests that, a unit increase in herd size increased the participation of smallholder farmers in markets. They therefore concluded that herd size exerts a significant positive effect on market participation variables. Conventional logic assumes that the larger number of livestock owned, the more likely farmers will participate in markets, either to sell stock or acquire necessary inputs such as drugs or supplements. This also applies among crop farmers, where 
Astewel (2010) and Omiti et al. (2009) among others, avowed that increasing volumes of production also increased their market participation. The result from this study however, aligns with the view expressed by Gwaka (2017), of the social and cultural relationship of livestock systems within rural societies, such as in the study area. Within these societies, livestock is kept as both status symbol and store of wealth, and only utilized for traditional and marital ceremonies.

Finally, the present study found that users of ICTs participated more in markets as compared to non-users. ICT-based sources increase access to reliable market information, as well as information from potential exchange partners which Ouma et al. (2010) declared as one of the key factors for improving smallholder farmer's participation in markets. A number of studies (Zoltner and Steffen 2013; Torero 2011; Payne 2011) have shown the benefits from using ICTs to disseminate information to users, especially in developing countries, and how it is a viable approach to linking smallholder farmers with markets. Langat and Litondo (2016) concluded that ICTs have significant effects on marketing decisions among smallholder farmers.

\section{Conclusion and Recommendations}

The socio-economic characteristics of smallholder farmers were identified to contribute to their participation in markets, and among these features their gender, age, marital status, educational level, household size, additional income, membership of a cooperative, herd size and use of ICTs were explored. The results from the data analysed show that gender difference was not a contributory factor to market participation, as all gender groups participated equally in the market. Age of the farmer contributed to their market participation, and showed a decline among older farmers in the study. Furthermore, the study found that marital status, level of education, size of household and herd size (for livestock farmers) did not make any difference to market participation among the study respondents. However, having an additional income source increased the number of respondents who participated in markets, and is considered a positive driver of market participation in this study. Also membership of a cooperative or association was noted to make a difference among respondents, as members participated extensively in markets with non-members failing to participate in markets. The benefits from membership of a farmer association or cooperative have been well documented, and as shown from this study, facilitates increased participation in markets among members. Users of ICTs also showed increased market participation in this 
study, and the association between using ICT sources and market participation fits the narrative of how accurate and timely market information enhances participation in markets.

Based on findings from this study the following recommendations are made:

- The continued roll out of project interventions that provide equal opportunities for both men and women, to improve and increase their agricultural enterprise while at the same time receiving equal support services and recognition.

- Design of support and improvement schemes that target young farmers, to enable access to required inputs and infrastructure for increased market participation.

- Increased extension support services providing market and production information through local community platforms. This will engage more farmers especially those who have limited educational achievements.

- Other livelihood support activities in communities that generate additional incomes for rural households. This will improve access to additional incomes and increased market participation.

- Support toward existing and new farmer associations or cooperatives for smallholder farmers, which will enable increased production and marketing opportunities.

- Dissemination of relevant market information using existing and new ICT-based sources which are widely accessible in rural communities, and affordable among smallholder farmers.

For future research, we recommend studies using long-term data among crop farmers, and also carried out in a wider area where smallholder farmers reside. The results from this study may not be generalized to all smallholder farmers, as it targeted selected livestock farmers within a specific district. It however contributes to scholarly output aimed at improving market access, market participation and commercialization among smallholder farmers in South Africa.

\section{Acknowledgement}

The author acknowledges the support provided by the URIC- research grant from the Central University of Technology, South Africa. 


\section{References}

Abayne, Y. and Tefera, T. 2013. Factors influencing market participation decision and extent of participation of haricot bean farmers in Meskan District, Ethiopia. International Journal of Management and Development Studies, Vol. 2(8): 17-26.

Adeoti, A., Oluwatayo, I.B. and Soliu, R.O. 2014. Determinants of market participation among maize producers in Oyo State, Nigeria. British Journal of Economics, Management and Trade, Vol. 4(7): 1115 - 1127.

Adeoye, I. and Adegbite, O. 2018. Determinants of smallholder plantain farmers' participation in markets. Journal of Innovation in Agriculture, Vol. 5(1): 5-12.

Adenegan K.O., Adepoju, A. and Nwauwa, L.O. 2012. Determinants of Market Participation of Maize Farmers in Rural Osun State of Nigeria. International Journal of Agricultural Economics \& Rural Development, Vol. 5(1): 28-39.

Arega, D.A., Manyong, V.M., Omanya, G., Mignouna, H.D., Bokanga, M. and Odhiambo, G. 2007. Smallholder Market Participation under Transactions Cost: Maize Supply and Fertilizer Demand in Kenya. Journal of Food Policy, Vol. 33(1): 318-328.

Asfaw, S., Amare, M., Lipper, L. and Davis, B. 2011. Welfare effects of market participation under transaction costs: evidence from Tanzania. Conference Paper. Agricultural Development Economics Division (ESA), Rome, Italy. .

Astewel, T. 2010. Analysis of Rice Profitability and Market chain: The Case of Fogera Woreda, South Gondar Zone, Amhara National Regional State, Ethiopia. Unpublished Thesis. School of Graduate Studies, Haramaya University Ethiopia.

Bahta, S. and Bauer, S. 2012. Policy options for improving market participation and sales of smallholder crop producers: A case study of Free State province of South Africa. African Journal of Agricultural Research, Vol. 7(4): 3525-3533.

Barrett, C., M. Bachke, M. Bellamare, H. Michelson, S. Narayana, and T. Walker. 2010. 'Smallholder Participation in Agricultural Value Chains: Comparative Evidence from Three Countries.' MPRA Paper No. 27829. University Library of Munich, Germany.

Badiane, O. 2014. Collective Action among African Smallholders: Trends and Lessons for Future Development Strategies. WCAO Thematic Research Note No. 5, International Food Policy Research Institute (IFPRI).

Baloyi, S. and Anim, F.D.K. 2018. Socio-economic Analysis of Factors Affecting Access to Markets by Smallholder Cooperative Vegetable Farmers. Journal of Human Ecology, Vol. 62(3): 35-40.

Barrett, C.B. 2008. Smallholder Market Participation: Concepts and Evidence from Eastern and Southern Africa. Journal of Food Policy, Vol. 34(2): 299-317.

Bellemare M.F. and Barrett C.B. 2006. An Ordered Tobit Model of Market Participation: Evidence from Kenya and Ethiopia. American Journal of Agricultural Economics, Vol. 88 (2): $324-337$. 
Boughton, D., Mather, D., Barret, C.B., Benefica, R., Abdula, D., Tschirley, D. and Cunguara, B. 2007. Market participation by rural households in a low-income country. An assetbased approach applied to Mozambique. Faith and Economics, Vol. 50(1): 64-101.

Chirwa, E.W. and Matita, M. 2012. From subsistence to smallholder commercial farming in Malawi: A case of NASFAM commercialization initiatives. Future Agricultures, Working Paper 037. Available at www.futures-agricultures.org (Accessed on 13/11/2018).

Egbetokun, O.A. and Omonona, B.T. 2012. Determinants of Farmers' Participation in Food Markets in Ogun State. Global Journal of Science Frontier Research, Agriculture and Veterinary Science, Vol. 12(9): 25 -30.

Food and Agriculture Organization. 2010. Gender and Land Rights Database. Available online at: http://www.fao.org/docrep/012/a1059e/al059e00.pdf. (Accessed on 26/04/2018).

Gwaka, L.T. 2017. Digital Technologies and Sustainable Livestock Systems in Rural Communities. Electronic Journal of Information Systems in Developing Countries. Vol. 81(6): 124.

Jari, B., and Fraser, G. 2012. Influence of institutional and technical factors on market choices of smallholder farmers in the Kat River Valley. In H. D. van Schalkwyk, J.A. Groenewald, G. C. G. Fraser, A. Obi, \& A. van Tilburg (Eds.), Unlocking markets to smallholders: Lessons from South Africa (pp. 59- 89). Netherlands: Wageningen Academic Publishers.

Khapayi, M. and Celliers P.R. 2016. Factors limiting and preventing emerging farmers to progress to commercial agricultural farming in the King William's Town area of the Eastern Cape Province, South Africa. South African Journal of Agricultural Extension, Vol. 44(1): 25-41.

Langat, R. and Litondo, K. 2016. Information and Communication Technologies and marketing decisions among small scale farmers in Kenya: Review of Evidence. International Journal of Economics, Commerce and Management, Vol. 4(4): 1167 - 1180.

Mathenge, M., Frank, P., John, O. and Dagmar, M. 2010. Participation in agricultural markets among the poor and marginalized: analysis of factors influencing participation and impacts on income and Poverty in Kenya. Study Report, World Agro-Forestry Centre.

Martey, E., Etwire, P., Wiredu, A. and Dogbe, W. 2014. Factors influencing willingness to participate in multi-stakeholder platform by smallholder farmers in Northern Ghana: Implications for research and development. Agricultural and Food Economics, 2(11): $1-15$.

Martey, E., Al-Hassan, R. and Kuwornu, J. 2012. Commercialization of smallholder agriculture in Ghana: A Tobit regression analysis. African Journal of Agricultural Research, Vol. 7(14), 2131-2141.

Matous, P., Todo, Y. and Pratiwi, A. 2015. The role of motorized transport and mobile phones in the diffusion of agricultural information in Tanggamus Regency, Indonesia. Available online: $\quad$ http://link.springer.com/article/10.1007/511116-015-9646/fulltext.html (accessed on 10/03/2019). 
Mbitsemunda, J. and Karangwa, A. 2017. Analysis of factors influencing market participation of smallholder beans farmers in Nyanza District of Southern Province, Rwanda. Journal of Agricultural Science, Vol. 9(11): 99-111.

Milanovic, S. 2014. The role and potential of information technology in agricultural improvement. Economics of Agriculture, Vol. 2(2014): 471 - 485.

Montshwe, B.D. 2006. Factors affecting participation in mainstream cattle markets by small-scale cattle farmers in South Africa. Unpublished Thesis. Faculty of Natural and Agricultural Sciences. University of Free State, Bloemfontein, South Africa.

Musah, A., Bonsu, O. and Seini, W. 2014. Market participation of smallholder maize farmers in the upper west region of Ghana. African Journal of Agricultural Research, Vol. 9(31): 2427-2435.

Mwangi, M., Ngigi, M. and Mulingi, W. 2015. Gender and age analysis on factors influencing output market access by smallholder farmers in Machakos County, Kenya. African Journal of Agricultural Research, Vol. 10(40): 3840-3850.

Mwombe, S., Mugivane, F., Adolwa, I. and Nderitu, J. 2013. Evaluation of Information and Communication Technology Utilization by Smallholder Banana Farmers in Gatanga District, Kenya. The Journal of Agricultural Education and Extension, Vol. 20(2): 247-261.

Neves, D.; Du Toit, A. 2013. Rural livelihoods in South Africa: Complexity, vulnerability and differentiation. Journal of Agrarian Change, Vol. 13(1): 93-115

Ngqangweni, S., Mmbengwa, V., Myeki, L., Sotsha, K. and Khoza, T. 2016. Measuring and Tracking Smallholder Market Access in South Africa. Working paper No. 3. National Agricultural Marketing Council. Available online at https://www.namc.co.za/researchportal/wp/2016/03.pdf (Accessed on 10/11/2019).

Nwafor Christopher and Carlu van der Westhuizen. 2020. Prospects for Commercialization among Smallholder Farmers in South Africa: A Case Study. Journal of Rural Social Sciences, 35(1): Article 2. Available at: https://egrove.olemiss.edu/jrss/vol35/iss1/2

Nwafor, CU., Ogundeji, AA., and van der Westhuizen, C. 2020. Adoption of ICT-based Information Sources and Market Participation among Smallholder Livestock Farmers in South Africa. In press: Agriculture (MDPI).

Nwafor, CU. 2019. Adoption of ICT-based market information sources in commercialising smallholder livestock farming systems: a case study of the Alfred Nzo District, Eastern Cape Province, South Africa. Unpublished Doctoral Thesis. Department of Agriculture, Faculty of Health and Environmental Sciences. Central University of Technology, Free State, South Africa.

Nwalem, P., Ukpe, H., Djomo, F. and Dzever, D. 2016. Factors influencing market participation among sesame farmers in Benue State, Nigeria. International Journal of Research Studies in Agricultural Sciences, Vol. 2(5): 1-5. 
Okello, J., Kirui, O., Gitonga, Z., Njiraini, G. and Nzuma, J. 2014. Determinants of Awareness and Use of ICT-based Market Information Services in Developing Country Agriculture: The Case of Smallholder Farmers in Kenya. Quarterly Journal of International Agriculture, Vol. 52(3): 263-282.

Okezie, C. A., J. Sulaiman, and A. C. Nwosu. 2012. Farm-Level Determinants of Agricultural Commercialization. International Journal of Agriculture and Forestry, Vol. 2(2):1-5.

Omiti, J.M., Otieno D.J., Nyanamba O.T. and McCullough, E. 2009. Factors influencing the Intensity of Market Participation by Smallholder farmers: A case of Rural and Peri-Urban Areas in Kenya. African Journal of Agricultural and Resource Economics, Vol. 3(1): $57-82$.

Osmani, A.G. and Hossain, E. 2015. Market participation of smallholder farmers and its determinants in Bangladesh. Review Article: Economics of Agriculture. Vol. 62(1): 163-179.

Ouma, E., Jagwe, J., Obare, G. and Abele, S. 2010. Determinants of smallholder farmers' participation in banana markets in Central Africa: The role of transaction costs. Agricultural Economics, Vol. 41(1): 111-122.

Payne, J. 2011. Using ICT to provide agriculture market price information in Africa. Briefing Paper. USAID. FACET-FIELD LWA Project. United States Agency for International Development.

Pradhan, K., R. Dewina, and B. Minten. 2010. Agricultural Commercialization and Diversification in Bhutan. IFPRI Report Summary. July 2010. International Food Policy Research Institute, Washington, DC, USA.

Reyes, B., Donovan, C., Bernsten R. and Maredia, M. 2012. Market participation and sale of potatoes by smallholder farmers in the central highlands of Angola: A double hurdle approach. Presentation at the International Association of Agricultural Economists (IAAE) Triennial Conference, Foz do Iguaçu, Brazil, 18-24 August, 2012.

Sebatta, C., Mugisha, J. and Katungi, E. 2014. Smallholder Farmers' Decision and Level of Participation in the Potato Market in Uganda. Modern Economy, 5, 895-906.

Siziba, S., Nyikahadzoi K., Diagne, A, Fatunbi, A.O, and Adekunle, A.A. 2011. Determinants of cereal market participation by Sub-Saharan Africa smallholder farmers. Learning Publics Journal of Agriculture and Environmental Studies, Vol. 2(1): 180-193.

Torero, M. 2011. A Framework for Linking Small Farmers to Markets. Conference on New Directions for Smallholder Agriculture. 24-25 January, Rome. International Fund for Agricultural Development (IFAD).

United Nations. 2012. The Future We Want. Outcome document of the United Nations Conference on Sustainable Development 2012. New York.

Zoltner, J. and Steffen, M. 2013. An assessment of market information systems in East Africa. Briefing Paper, USAID- FACET/ FIELD-support LWA Project. Available at: https://d3a8pro7vhmx.cloudfront.net/eatradehub/pages/1134.pdf (accessed on 28/11/2018). 